\title{
Free software for vision stimulation services
}

\author{
"Software" livre para serviços de estimulação visual
}

Priscila Batista Martins ${ }^{1}$, Anita Zimmermann ${ }^{1}$, Rodrigo Pessoa Cavalcanti Lira ${ }^{2}$

\begin{abstract}
Purpose: To develop free software (SAEVI) to improve the vision stimulation services. Methods:The software of visual stimulation service (SAEVI) was developed in microsoft Acess ${ }^{\circledR}$, version 2003. Results: This database management system allows an efficient patients control and specific patient's appointments, such as: ophthalmological diagnostic and year of the appointment, and also other options, providing reports of each item. Conclusion: Professionals who work with visual stimulation or in related areas may be benefited from using the software to organize their work routines.
\end{abstract}

Keywords: Software; Database management systems; Visual stimulation

\section{Resumo}

Objetivo: Desenvolver software livre(SAEVI) para aprimorar serviço de estimulação visual. Métodos: Foi desenvolvido software para Ambulatório de Estimulação Visual (SAEVI) utilizando-se microsoft Acess®, versão 2003. Resultados: Este sistema de gerenciamento de banco de dados permitecontrole eficaz dos pacientes atendidos, consultasespecíficas aos mesmos,como:diagnóstico oftalmológico e ano da consulta, bem como outras opções, fornecendo relatórios de cada item. Conclusão: Profissionais que trabalhamcom estimulação visualou áreas afins,podemse beneficiar com a utilização do software para organizar suas rotinas detrabalho.

Descritores: Software, Sistemas de gerenciamento de banco de dados; Estimulação luminosa

\footnotetext{
${ }^{1}$ Universidade Estadual de Campinas (UNICAMP) - Campinas (SP), Brazil;

${ }^{2}$ Universidade Estadual de Campinas (UNICAMP) - Campinas (SP), Brazil. Study carried out at Visual Stimulation Ambulatory, Ophthalmology Subject, Medical Science College, Universidade Estadual de Campinas (UNICAMP) Campinas (SP), Brazil.
}

Os autores declaram inexistir conflitos de interesse

Recebido para publicação em 20/7/2011 - Aceito para publicação em 11/6/2011 


\section{INTRODUCTION}

$\mathbf{T}$ The information systems provide data without considering priorities and activities, though it is necessary to develop mechanisms that allow a higher control of information flow, aiming to assure the content in all levels of management ${ }^{(1)}$.

A database or a series of records was arranged in a regular structure, allowing the same reorganization and a production of information that can be kept and accessed by software known as database management system (DBMS). The data presentation is similar to spreadsheet; however, database management systems have specific characteristics for storage, classification and management integrity data recovery ${ }^{(2)}$.

Searching health information databases allow the management of researches and specific reports, aiming to perform, control and measure information systems, procedures and routine primary, secondary and tertiaryhealth care ${ }^{(3)}$.

With the purpose of computerizing the tasks provided by a vision stimulation service, a database management system was set to patient's information storage, improving treatment routines.

\section{Methods}

The software for clinical of visual stimulation (SAEVI) was developed by using microsoft Acess ${ }^{\circledR}$, version $2003^{(4)}$.

The entry of patients includes personal data, diagnostics, procedures and conduct.

It is possible to make queries according to their specificities. Data could be exported to other applications compatible to Access ${ }^{\circledR}$.

To obtain SAEVI send e-mail to saeviuni camp@ gmail.com
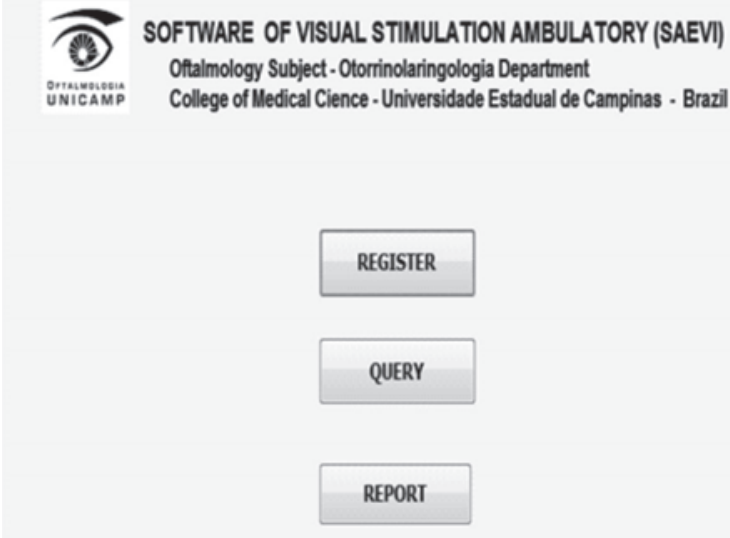

Figure : Layout - main form open screen

SOFTWARE OF VISUAL STIMULATION AMBULATORY (SAEVI) Oftalmology Subject - Otorrinolaringologia Department College of Medical Cience - Universidade Estadual de Campinas - Brazil
It is necessary to have some version of Windows as the operational system and the Acess ${ }^{\circledR}$ program version 2003 or a compatible one installed in the computer. Once the program is initiated, open the file and choose desired option at the main form (Figure 1); layout of opening screen of the main form.

In the option register (Figure $2 \mathrm{~A}$ ) layout of register main screen; (Picture 2B) are typed the following information about the patient: HC number (patient register at the hospital), patient's name, sex, date of appointment, year of appointment, address, city, postal code, state, telephone, mobile phone, date of birth, place of birth, parent's names, ophthalmic diagnostic, other diagnosis - comorbidities, date of the first ophthalmologic, types of therapy, therapy places, other information.

In the option Query (Figure3A), it is possible to make queries by the patient's HC number, patient's name, diagnosis or year of the appointment (Figure 3B). From these queries, the following information are provided: HC number, patient's name, sex, date of appointment, year of appointment, address, city, postal code, state, telephone, mobile phone, date of birth, place of birth, parent's names, ophthalmic diagnostic, other diagnoses comorbidities, date of the first ophthalmologic, types of therapy, therapy places, other information.

In the option report (Figure 4A), it is possible to create records based on the $\mathrm{HC}$ number, patient's name, diagnosis or year of appointment (Figure 4B). A report will be provided, containing the names of the registered patients along with all their information.
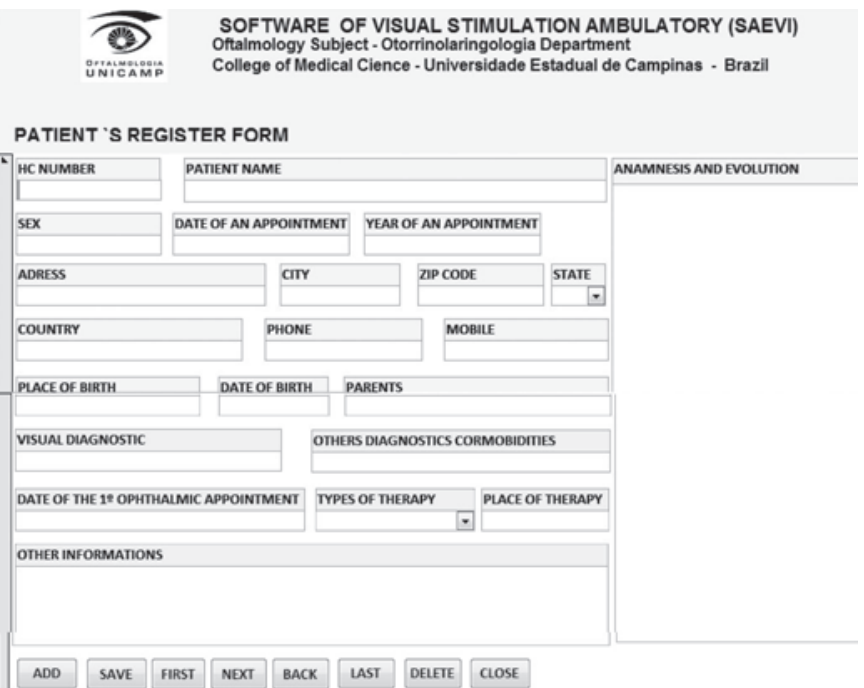

Figurre 2B: Register screen layout

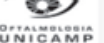
SOFTWARE OF VISUAL STIMULATION AMBULATORY (SAEVI) Oftalmology Subject - Otorrinolaringologia Department College of Medical Cience - Universidade Estadual de Campinas - Brazil QUERY

\section{REGISTER}

\section{PATIENT}

Figure 2A: Layout of register main screen

DIAGNOSTIC

HC NUMBER

YEAR

PATIENT NAME 


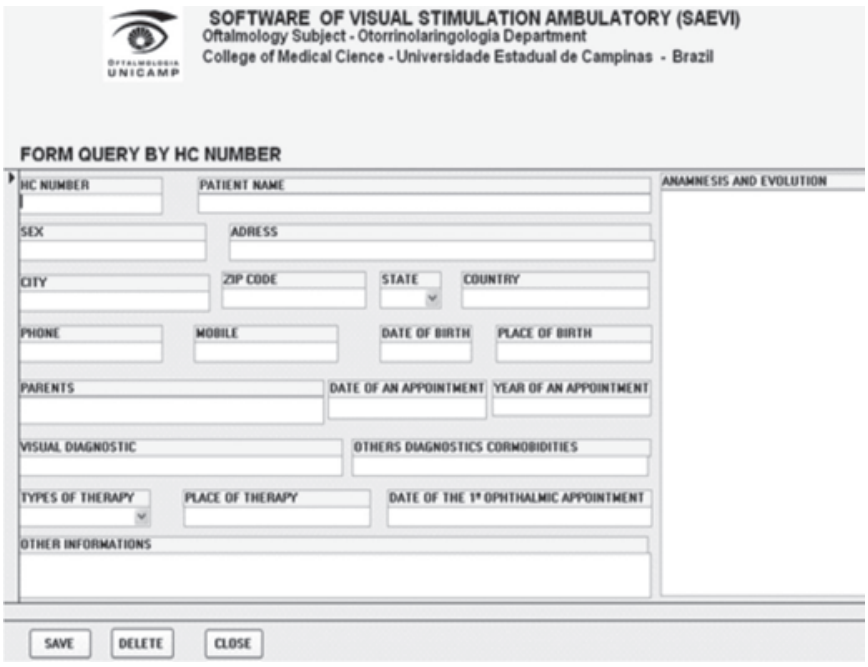

Figure 3B: Layout of query form screen by HC number

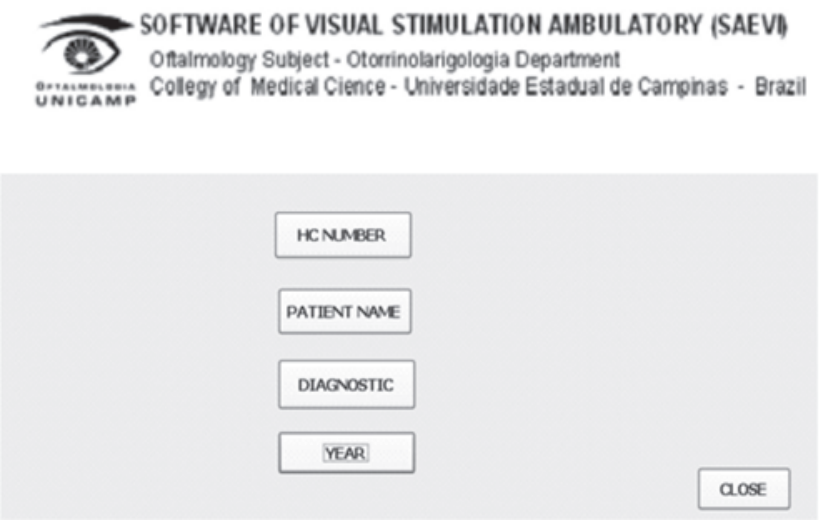

Figure 4A: Report screen layout

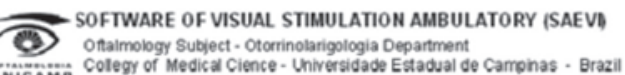

\section{REPORT YEAR}

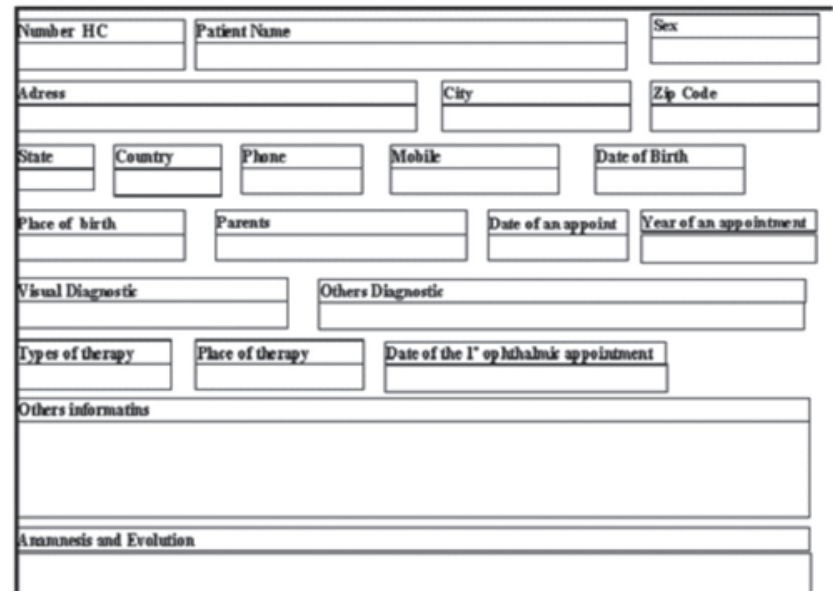

Figure 4B: Layout of year report screen

\section{Discussion}

The health information system (SIS) ${ }^{(5,6)}$ is considered a vehicle necessary to managing services, organizing and analyzing data in order to define problems and risks, as well as measuring the effectiveness, efficiency and influence that the delivered services may have on health conditions in the population. Guide the implementation, follow and measure health care models, involving actions of prevention and control of diseases ${ }^{(4,7)}$, contribute to knowledge production in health and related subjects.

There are non-charged database software to be used as auxiliary tools, like Firebird ${ }^{\circledR}$, which require specific programming knowledge. Other commercial software, like Prodoctor.net ${ }^{\circledR}$ and Totvs $^{\circledR}$, can alsobe used, resulting in purchase and maintenance costs.

After being used for care of patients in a vision stimulation service, SAEVI - a non-charged database program of free access - was already formatted for immediate use in other vision stimulation services, allowing the migration to other platforms, in case of more complex or commercial software.

\section{Conclusion}

Professionals from several healthcare segments, mainly those still less skilled, can be benefited from this database services and, from the suggested model, other software can be developed, according to the demand.

\section{ReferenCES}

1. Almeida MF. Descentralização de sistemas de informação e o uso das informações a nível municipal. Inf Epidemiol SUS. 1998;7(3):28-33.

2. Fontes D. Access - Conceito de banco de dados [Internet]. [citado 2010 Jul 06]. Disponível em: http://deivis24.blogspot.com/2009/ 03/access-conceito-de-banco-de-dados.html.

3. Barra DC, Nascimento ER, Martins JJ, Albuquerque GL, Erdmann AL.Evoluçâo histórica e impacto da tecnologia na área da saúde e da enfermagem. Rev Eletrônica Enferm. 2006;8(3):422-30.

4. Ferreira SM. Sistema de informação em saúde. In: Brasil. Ministério da Saúde. Gestão Municipal de Saúde: textos básicos. Rio de Janeiro: Ministério da Saúde; 2001. p. 171-91.

5. Brasil. Ministério da Saúde. Funasa. Sistemas de informação em saúde e a vigilância epidemiológica. Inf Epidemiol SUS. 1994;3(1):61.

6. Brasil. Ministério da Saúde. Funasa. Sistemas de informação em saúde. Inf Epidemiol SUS. 1995;4:85-92.

7. Moraes IH. Política, tecnologia e informação em saúde: a utopia da emancipação. Salvador: Casa da Qualidade; c2002.

\section{Autor correspondente:}

Rua Antônio Luís Carbone, $\mathrm{n}^{\circ}$ 78,

CEP 13083-050 - Campinas (SP), Brazil

Fax: (19) 32439040,

E-mail: anitazsd@fcm.unicamp.br 